\title{
KEMAMPUAN LITERASI MATEMATIKA MAHASISWA DALAM MODEL PROBLEM BASED LEARNING MELALUI DARING
}

\author{
Anita Sri Rejeki Hutagaol ${ }^{1}$, \& Nurapni Sopia ${ }^{2}$ \\ ${ }^{1,2}$ Program Studi Pendidikan Matematika, STKIP Persada Khatulistiwa \\ Email: boruhutagaolbest@gmail.com ${ }^{1}$, nurapni22sopia@gmail.com ${ }^{2}$
}

\section{INFO ARTIKEL}

Riwayat Artikel:

Menerima : 12 Agustus 2020

Revisi : 27 Oktober 2020

Diterima : 09 Nopember 2020

\section{Kata Kunci:}

Daring, Literasi Matematika,

Problem Solving
Keywords:

Online, mathematics literacy, Problem Based Learning

\section{Korespondensi:}

Nurapni Sopia

Program Studi Pendidikan

Matematika, STKIP Persada

Khatulistiwa

Email:

boruhutagaolbest@gmail.com

\section{ABSTRAK}

Penelitian dilatarbelakangi dengan belum optimalnya literasi matematika mahasiswa. Oleh karena itu, penelitian ini bertujuan untuk meningkatkan kemampuan literasi matematika mahasiswa dalam model Problem Based Leraning melalui daring. Penelitian berbentuk Penelitian Tindakan Kelas yang dilaksanakan dalam 2 siklus. Alat pengumpul data yaitu lembar observasi, lembar tes dan angket. Subjek penelitian adalah mahasiswa PGSD, sedangkan objek penelitiannya adalah model Problem Based Leraning melalui daring. Analisis data menggunakan teknik analisis interaktif. Berdasarkan hasil penelitian diperoleh bahwa: (1) Hasil observasi keterlaksanaan pembelajaran pada siklus I dan pada siklus II sebesar 3.60 dengan kategori cukup baik; (2) Hasil belajar dengan nilai rata-rata siklus I sebesar 70.26, sedangkan pada siklus II mengalami peningkatan menjadi 90.99 dengan kategori baik, dengan ketuntasan sebesar $80.63 \%$ pada siklus I dan II; (3) Respon mahasiswa $93.86 \%$ dengan kategori sangat positif. Dengan demikian, dapat disimpulkan bahwa model Problem Based Leraning melalui daring dapat meningkatkan kemampuan literasi matematika mahasiswa.

\section{ABSTRACT}

This research is motivated by not optimal students'mathematical literacy. Therefore, this research aimed to improve students' mathematical literacy skills in Problem Based Learning model via online. The research was Classroom Action Research form which carried out in 2 cycles. Data collection tools are observation sheets, test sheets and questionnaires. Research subjects were PGSD students, while research object was problembased learning modelvia online. The research showed that: (1) observation results of learning implementation in first cycle and second cycle were 3.60 in the fair category; (2) learning result with an average value in first cycle were 70.26, while in second cycle it has increased were 90.99 in a good category, with completeness were $80.63 \%$ in cycles I and II; (3) Student response were $93.86 \%$ in a very positive category. Thus, it can be concluded that Problem Based learning model viaonline can improve students' mathematical literacy skills

\section{PENDAHULUAN}

Perkembangan teknologi menuju revolusi industri 4.0 menyebabkan perubahan dari berbagai segi aspek kehidupan dan tidak lepas dari perkembangan ilmu pengetahuan satu diantaranya matematika. Menurut Ojose
(2011), matematika merupakan ilmu universal yang mendasari perkembangan teknologi modern, mempunyai peran penting dalam berbagai disiplin dan mengembangkan daya pikir manusia. Matematika mempunyai peran yang sangat penting sehingga disebut sebagai 
ratu dari semua ilmu. Pendidikan matematika dapat meningkatkan kemampuan berpikir kritis, logis, sistematis dan kreatif serta bernalar.Sesuai dengan tujuan pembelajaran matematika yang dikemukakan oleh Firmansyah (2013) yakni: 1) melatih cara berfikir dan bernalar dalam menarik kesimpulan; 2) mengembangkan aktivitas kreatif yang melibatkan imajinasi, intuisi, dan penemuan dengan mengembangkan pemikiran divergen, orisinil, rasa ingin tahu, membuat prediksi dan dugaan, serta mencoba-coba; 3) mengembangkan kemampuan pemecahan masalah; dan 4) mengembangkan kemampuan menyampaikan informasi atau mengkomunikasikan gagasan antara lain melalui pembicaraan lisan, grafik, peta, diagram, dalam menjelaskan gagasan tersebut.

Data dari Program for International Student Assesment (PISA) tahun 2016, Indonesia berada pada urutan 62 dari 70Negaramenunjukkan bahwa kemampuan peserta didik masih kurang dalam menyelesaikan permasalahan. Oleh sebab itu, seluruh peserta didik dalam hal ini mahasiswa diharapkan mampu berpikir kritis dan kreatif yang dapat dicapai dengan adanya kemampuan literasi matematika. Literasi matematika didefinisikan sebagai kemampuan seseorang dalam merumuskan, menggunakan dan menafsirkan matematika dalam berbagai konteks. Termasuk kemampuan melakukan penalaran secara matematis dan mengunakan konsep, prosedur, dan fakta untuk menggambarkan, menjelaskan atau memperkirakan suatu fenomena. Kusuma menyatakan bahwa manfaat literasi matematika tidak hanya sekedar pemahaman aritmatik namun lebih kepada penugasan pemecahan masalah yang membutuhkan penalaran serta mampu menggunakan logika dalam setiap pengambilan keputusan. Hal ini membuktikan bahwa pentingnya kemampuan literasi matematika dalam menyelesaikan masalah. Namun, berdasarkan fakta yang dapat diketahui dari laporan studi PISA tahun 2015. Rata-rata skor peserta didik Indonesia untuk kemampuan literasi matematis adalah 375 (level 1) sedangkan rata-rata skor internasional adalah 500 (level 3). Level 1 adalah level terendah dari 6 level kemampuan literasi matematis yang diterapkan PISA (OECD, 2016). Hasil PISA tersebut menunjukkan kemampuan literasi matematika siswa Indonesia yang belum optimal.

Mahasiswa program studi PGSD di STKIP Persada Khatulistiwa Sintang mengikuti pembelajaran matematika SD merupakan mata kuliah wajib dalam kurikulum yang telah diberlakukan pada program studi tersebut. Adapun tujuan kegiatan pembelajaran yakni agar mahasiswa memperoleh pengalaman belajar serta meningkatnya kemampuan literasi matematika. Namun demikian, kenyataan mahasiswa cenderung menghafal konsep, mengerjakan tugas yang diberikan dosen, dan kurang mampu menyelesaikan soal-soal yang memuat level literasi matematika. Ditambah lagi masa sekarang, dunia pendidikan mengalami dilemma dalam proses pembelajaran. Sehingga, penerapan social distancing wajib dilakukan dan menjadi tantangan bagi mahasiswa sebagai calon guru 
masa depan. Upaya mengatasi hal tersebut kegiatan pembelajaran dilaksanakan melalui daring agar proses dan tujuan pembelajaran dapat tercapai. Terkait uraian tersebut, dosen memiliki tanggungjawab membimbing mahasiswa untuk aktif, kreatif, inovatif, dan dapat memilih model pembelajaran sesuai dengan tujuan yang akan dicapai dengan memberikan soal-soal yang memuat level literasi matematika kendatipun melalui pembelajaran daring.Melihat pentingnya kemampuan literasi matematika maka mahasiswa dituntut untuk memiliki kemampuan ini.Upaya peningkatan kualitas pembelajaran dapat melalui pemilihan model pembelajaran yang tepat dan inovatif, salah satunya model pembelajaran Problem Based Learning (PBL).Menurut Dzulfikar (2012), Problem Based Learning adalah model pembelajaran dengan pendekatan pembelajaran peserta didik pada masalah autentik sehingga peserta didik dapat menyusun pengetahuannya sendiri, menumbuhkembangkan keterampilan yang lebih tinggi dan inkuiri, memandirikan peserta didik, dan meningkatkan kepercayaan diri sendiri. Hasil penelitian (6) Istiandaru, dkk; Hasil penelitian menunjukkan bahwa perangkat pembelajaran dinilai valid oleh para ahli dengan kategori sangat baik. Perangkat pembelajaran dapat dikategorikan praktis dengan merujuk pada siswa dan guru merespon positif, serta kemampuan guru dalam mengelola pembelajaran dikategorikan tinggi.Pembelajaran juga efektif meningkatkan kemampuan literasi matematika siswa. (7)Madyaratri, dkk; menyataka dalam peneltianya Terdapat tujuh komponen kemampuan yang terdapat dalam literasi matematis yaitu (1) komunikasi, matematisasi, (3) menyajikan kembali, (4) menalar dan memberi alasan, (5) menggunakan strategi pemecahan masalah, (6) menggunakan simbol, bahasa formal dan teknik, (7) menggunakan alat matematika. Hasil kajian diperoleh bahwa diprediksi pembelajaran problem based learning dengan tinjauan gaya belajar merupakan pembelajaran yang efektif digunakan untuk meningkatkan kemampuan literasi matematika serta (8) Rahmat, dkk, penelitian yang dilakukan dilatar belakangi oleh rendahnya kemampuan literasi matematis dan kemandirian belajar peserta didik. Artikel ini bertujuan untuk mendeskripsikan peran model PBL terhadap kemampuan literasi matematis dan kemandirian belajar. Jenis penelitian yang digunakan pada artikel ini adalah penelitian deskriptif kuantitatif yang dilakukan pada peserta didik kelas VIII MTs Darul Wasi'ah Simalinyang melalui wawancara dengan peserta didik dan guru, observasi, dan kajian literatur yang dianalisis secara deskripti. Berdasarkan penelitian terdahulu tersebut bahwa Problem Based Learning dapat mengukur kemampuan literasi matematika peserta didik.

Berdasarkan uraian di atas, peneliti tertarik untuk melakukan penelitian dengan judul "Kemampuan Literasi Matematika Mahasiswa dalam Model Problem Based Learning Melalui Daring". Tujuan dari penelitian ini yakni untuk meningkatkan kem ampuan literasi matematika mahasiswa 
menggunakan model Problem Based Learning melalui daring pada mata kuliah pembelajaran matematika SD.

\section{METODE PENELITIAN}

Metode penelitian pada dasarnya merupakan cara ilmiah untuk mendapatkan data dengan tujuan dan kegunaan tertentu (Sugiyono, 2016). Selanjutnya Sugiyono (2016), menyatakan bahwa "Metode kualitatif adalah metode penelitian yang digunakan untuk meneliti kondisi obyek yang alamiah, dimana peneliti ini adalah sebagai intrument kunci, teknik pengumpulan data dilakukan secara trianggulasi (gabungan), analisis data bersifat induktif/kualitatif, dan hasil penelitian kualitatif lebih menekankan makna dari pada generalisasi.

Bentuk penelitian yang digunakan adalah Penelitian Tindakan Kelas (Classroom Action Research). Model Penelitian Tindakan Kelas yang digunakan dalam penelitian ini adalah model Kurt Lewin. Penelitian Tindakan Kelas model Kurt Lewin memiliki empat tahapan dalam satu siklus, yang terdiri dari perencanaan (planning), pelaksanaan tindakan (acting), pengamatan (observing), dan refleksi (reflecting). Lokasi atau tempat melaksanakan penelitian ini adalah mahasiswa PGSD semeter IV kelas A9 pada mata kuliah pembelajaran matematika SD. Teknik pengumpulan data yang digunakan Penelitian Tindakan Kelas ini adalah teknik observasi, teknik tes, teknik kuesioner tidak langsung, dan teknik dokumentasi. Alat pengumpul data dalam penelitian yaitu lembar keterlaksanaan pembelajaran, tes kemampuan literasi matematika mahasiswa, dan lembar respon mahasiswa. Teknik analisis data dalam penelitian ini menggunakan teknik analisis model Miles and Huberman. Miles and Huberman (Sugiyono, 2013), mengemukakan bahwa aktivitas dalam analisis data kualitatif dilakukan secara interaktif dan berlangsung secara terus menerus sampai tuntas. Sehingga datanya sudah jenuh. Aktivitas dalam analisis data, yaitu pengumpulan data, reduksi data, penyajian data dan kesimpulan.

Adapun jenis data yang dianalisis adalah Analisis Kevalidan Perangkat Pembelajaran Validasi ini didasarkan pada pendapat tiga orang ahli dalam bidang pendidikan matematika. Berdasarkan pendapat ahli tersebut akan ditentukan rerata nilai untuk setiap aspek, sehingga diperoleh nilai rata-rata total aspek. Kegiatan penentuan nilai rata-rata total aspek penilaian kevalidan soal tes mengikuti langkah- langkah berikut: Melakukan rekapitulasi data penilaian kevalidan perangkat pembelajaran ke dalam tabel yang meliputi: aspek $\left(\mathrm{A}_{\mathrm{i}}\right)$, indikator $\left(\mathrm{I}_{\mathrm{i}}\right)$, dan nilai $\mathrm{V}_{\mathrm{ji}}$ untuk tiap-tiap ahli. Menentukan rata-rata nilai dari ahli untuk setiap indikator dengan rumus:

$$
I_{i}=\frac{\sum_{j=1}^{n} V_{j i}}{n}
$$

dengan:

$\mathrm{V}_{j i}$ adalah data nilai dari penilai ke- $j$ terhadap indikator ke-i,

$n$ adalah banyaknya penilai (ahli dan praktisi)

Hasil yang diperoleh kemudian ditulis 
pada kolom dalam tabel yang sesuai.

Menentukan nilai $\mathrm{Va}$ atau nilai rerata total dari rerata nilai untuk semua aspek dengan rumus

$V a=\frac{\sum_{i=1}^{n} A_{i}}{n}$

dengan :

$V a$ adalah nilai rerata total untuk semua aspek

$A_{i}$ adalah rerata nilai untuk aspek ke- $i, n$ adalah banyaknya aspek

Hasil yang diperoleh kemudian ditulis pada kolom dalam tabel yang sesuai. Selanjutnya nilai $\mathrm{Va}$ atau nilai rerata total ini dirujuk pada interval penentuan tingkat kevalidan soal tes, sebagai berikut:

Tabel 1. Kriteria Tingkat Kevalidan

\begin{tabular}{ccc}
\hline No & $\begin{array}{c}\boldsymbol{V a} \text { atau nilai rerata } \\
\text { total }\end{array}$ & $\begin{array}{c}\text { Kriteria } \\
\text { Kevalidan }\end{array}$ \\
\hline 1 & $1 \leq \mathrm{Va}<2$ & Tidak valid \\
2 & $2 \leq \mathrm{Va}<3$ & Kurang valid \\
3 & $3 \leq \mathrm{Va}<4$ & Cukup valid \\
4 & $4 \leq \mathrm{Va} \leq 5$ & Sangat Valid \\
\hline
\end{tabular}

Kriteria menyatakan soal tes memiliki derajat validitas yang baik, jika minimal tingkat validitas yang dicapai adalah tingkat valid. Jika tingkat pencapaian validitas di bawah valid, maka perlu dilakukan revisi berdasarkan masukan (koreksi) para ahli. Selanjutnya dilakukan kembali kegiatan validasi. Demikian seterusnya hingga diperoleh perangkat pembelajaran yang ideal dari ukuran validitas isi dan konstruksinya.

Selanjutnya dianalisis sebagai hasil dari validitas ini dan akan dikategorikan ke dalam tabel berikut ini menurut skala likert (Widoyoko, 2015:69).

Tabel 2. Kategori Skor Validasi Soal Tes (Validator Ahli)

\begin{tabular}{ll}
\hline Interval Tingkat Pencapaian & Kategori \\
\hline $3.25<\mathrm{M} \leq 4.00$ & Sangat Baik \\
$2.50<\mathrm{M} \leq 3.25$ & Baik \\
$1.75<\mathrm{M} \leq 2.50$ & Kurang Baik \\
$0.00<\mathrm{M} \leq 1.75$ & Tidak Baik \\
\hline
\end{tabular}

Selanjutnya analisis data aktivitas mahasiwa Penentuan kriteria keefektifan aktivitas mahasiswa berdasarkan pencapaian waktu ideal yang ditetapkan dalam penyusunan soal tes menggunakan model Problem Based Learning melalui daring seperti yang terlihat pada Tabel 3 .

Kriteria pencapaian keefektivitas aktivitas mahasiswa dalam pembelajaran adalah jika keenam kategori aktivitas siswa di atas terpenuhi dengan toleransi 5\%. Dengan catatan kriteria batas toleransi 3 dan 5 harus dipenuhi. Sehingga keefektifan aktivitas siswa terpenuhi dan tidak mengalami revisi.

Analisis Data Kemampuan Dosen Mengelola Pembelajaran Kegiatan yang dilakukan untuk menganalisis data penilaian kemampuan dosen mengelola pembelajaran adalah sebagai berikut, melakukan rekapitulasi hasil penilaian pengamat ke dalam tabel yang meliputi: aspek $\left(\mathrm{A}_{\mathrm{j}}\right)$ dan kriteria $\left(\mathrm{k}_{\mathrm{i}}\right)$ untuk 2 rencana pembelajaran, Mencari nilai kategori (NK) dari nilai rata-rata kriteria $\left(\mathrm{NRK}_{i}\right)$ dalam setiap aspek penilaian dengan rumus:

$N K_{j}=\frac{\sum_{i=1}^{n} N R K_{i j}}{n}$ 
Mencari NKG dengan mencari rerata nilai kategori dengan rumus:

$$
N K G=\frac{\sum_{i=1}^{m} N K_{i}}{m}
$$

Kategori NKG menurut Sinaga (dalam Hutagaol,2015) interval penentuan tingkat kemampuan dosen mengelola pembelajaran dengan perangkat pembelajaran adalah sebagai berikut :

$$
\begin{array}{cl}
1 \leq N K G<2 & \text { Tidak baik } \\
2 \leq N K G<3 & \text { Kurang baik } \\
3 \leq N K G<4 & \text { Cukup Baik } \\
N K G=5 & \text { Baik }
\end{array}
$$

\section{Tabel 3. Keefektifan Aktivitas Mahasiswa}

\section{HASIL DAN PEMBAHASAN}

Hasil analisis lembar kemampuan dosen dalam mengelola pembelajaran siklus I dan siklus II disajikan pada gambar diagram berikut.

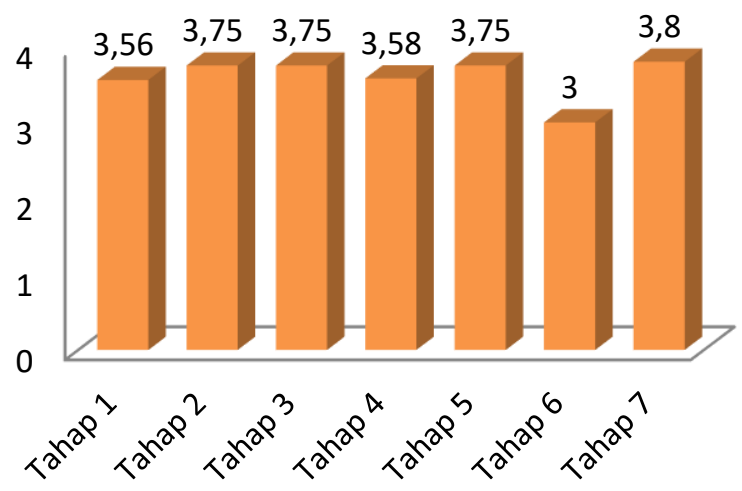

Kemampuan Dosen Mengelola Pembelajaran

Gambar 1. Diagram Nilai Perolehan Kemampuan Dosen dalam Mengelola Pembelajaran

Dari diagram 1, di atas terlihat bahwa dosen dalam mengelola pembelajaran masuk dalam kategori "cukup baik", hal ini terlihat

dari skor atau nilai yang diberikan pengamat terhadap kemampuan dosen dalam mengelola pembelajaran. Secara keseluruhan pembelajaran yang dikelola oleh dosen pada siklus I dan II berada pada kategori cukup baik, hal ini juga terlihat dari antusiasme mahasiswa dan dosen dalam proses pembelajaran. Sehingga berdasarkan hasil penilaian kemampuan dosen mengelola pembelajaran menggunakan model Problem Based Learning melalui daring ini efektif untuk digunakan dalam proses pembelajaran.

Selanjutnya persentase waktu ideal aktivitas mahasiswa peneliti dibantu oleh dua orang pengamat yang mengamati aktivitas mahasiswa sesuai dengan indikator-indikator

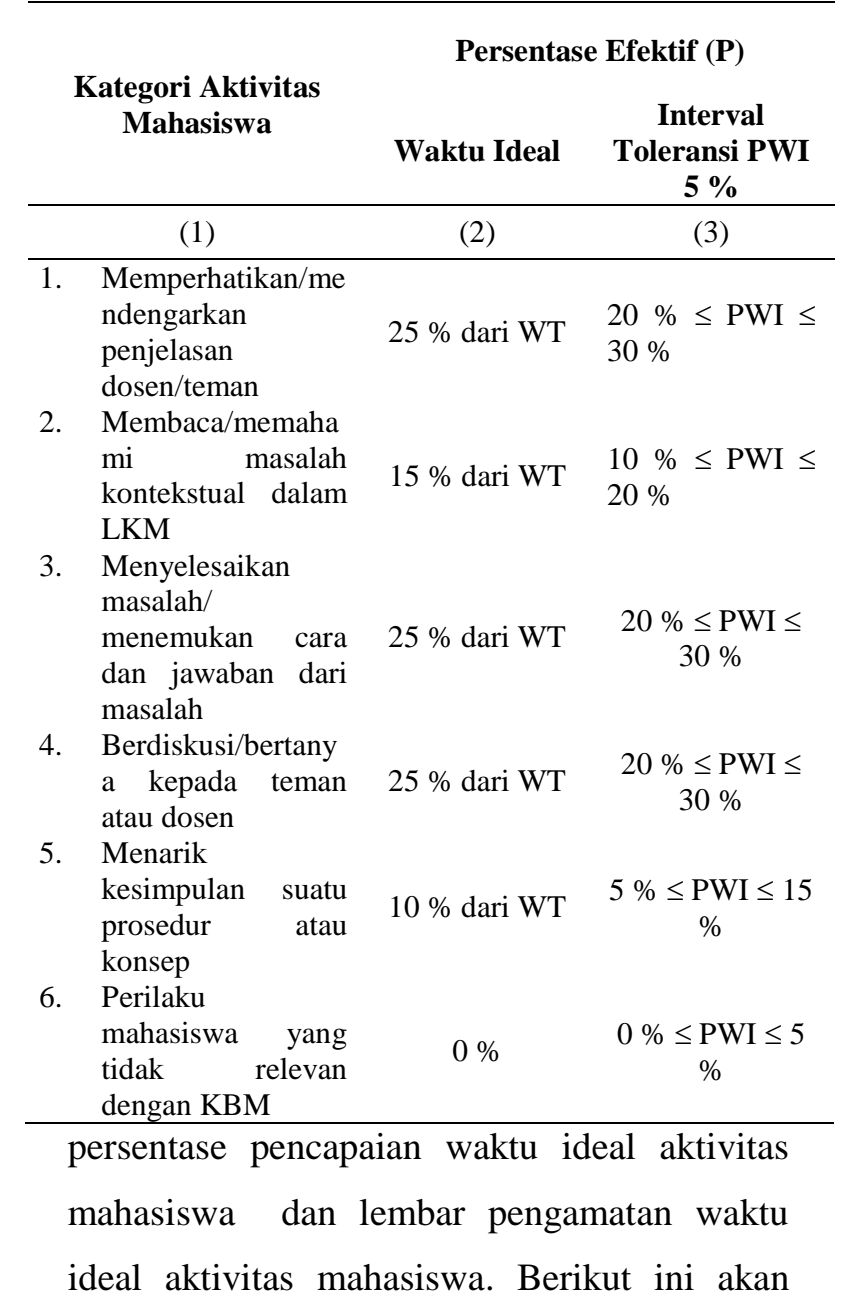


dijabarkan secara singkat persentase pencapaian waktu ideal aktivitas mahasiswa.

Tabel 4. Tabel Hasil Pengamatan Aktivitas Mahasiswa

\begin{tabular}{|c|c|c|c|c|c|c|c|}
\hline \multirow[b]{2}{*}{ No } & \multirow[b]{2}{*}{ Katagori Pengamatan } & \multicolumn{4}{|c|}{ Persentase Aktivitas Mahasiswa } & \multirow{2}{*}{$\begin{array}{c}\text { Rerata aktivitas } \\
\text { mahasiswa } \\
\text { keseluruhan } \\
\text { dalam Pembelajaran } \\
(\%)\end{array}$} & \multirow{2}{*}{$\begin{array}{l}\text { Kriteria } \\
\text { Batasan } \\
\text { Keefektifan } \\
\quad(\%)\end{array}$} \\
\hline & & $\begin{array}{l}\text { Pertemuan } \\
\text { I }\end{array}$ & $\begin{array}{l}\text { Pertemuan } \\
\text { II }\end{array}$ & $\begin{array}{l}\text { Pertemuan } \\
\text { III }\end{array}$ & $\begin{array}{l}\text { Pertemuan } \\
\text { IV }\end{array}$ & & \\
\hline 1. & $\begin{array}{l}\text { Memperhatikan } \\
\text { /mendengarkan penjelasan } \\
\text { dosen/teman dengan aktif }\end{array}$ & 20,9 & 21,96 & 21,96 & 22,30 & 21,78 & $20-30$ \\
\hline 2. & $\begin{array}{l}\text { Membaca/memahami } \\
\text { masalah kontekstual dalam } \\
\text { LKM }\end{array}$ & 14,7 & 16,22 & 15,88 & 15,88 & 15,67 & $10-20$ \\
\hline 3. & $\begin{array}{l}\text { Menyelesaikan masalah/ } \\
\text { menemukan cara dan } \\
\text { jawaban dari masalah }\end{array}$ & 24,6 & 22,64 & 23,31 & 23,65 & 23,55 & $20-30$ \\
\hline 4. & $\begin{array}{l}\text { Berdiskusi/ bertanya kepada } \\
\text { teman atau guru }\end{array}$ & 20,9 & 25,68 & 25,65 & 25,34 & 24,39 & $20-30$ \\
\hline 5. & $\begin{array}{l}\text { Menarik kesimpulan suatu } \\
\text { prosedur/ konsep }\end{array}$ & 14,3 & 12,50 & 12,50 & 12,50 & 12,95 & $5-15$ \\
\hline 6. & $\begin{array}{l}\text { Perilaku yang tidak relevan } \\
\text { dengan KBM }\end{array}$ & 4,4 & 1,01 & 0,68 & 0,34 & 1,61 & $0-5$ \\
\hline
\end{tabular}

Pada Tabel 5 dapat dilihat bahwa hasil

Berdasarkan tabel 4 di atas terlihat bahwa proporsi persentase waktu terbanyak yang dilakukan oleh mahasiswa adalah

berdiskusi/ bertanya kepada teman atau guru yaitu 24,39\%, menyelesaikan masalah/ menemukan cara dan jawaban dari masalah yaitu 23,55\%, memperhatikan/mendengarkan penjelasan dosen/teman dengan aktif yaitu $21,78 \%$, selanjutnya membaca/memahami masalah kontekstual dalam LKM yaitu $12,95 \%$, menarik kesimpulan suatu prosedur/ konsep yaitu 12,95\%. Aktivitas mahasiswa yang paling sedikit proporsi persentase waktu yang dilakukan oleh siswa adalah perilaku yang tidak relevan dengan KBM yaitu 1,61\%.

Berdasarkan hasil rekapitulasi aktivitas mahasiswa pada pertemuan I dan II siklus I dan pertemuan I dan II siklus II telah memenuhi keenam kategori aktivitas mahasiswa dengan toleransi $5 \%$ dan batas toleransi 3 dan 5 terpenuhi. tes pada siklus I untuk mengukur kemampuan literasi matematika mahasiswa secara klasikal diperoleh persentase ketuntasan 70,27\%. Selanjutnya presentase ketuntasan klasikal pada siklus II sebesar $90.99 \%$.

Tabel 5. Hasil Tes kemampuan Literasi Matematika Mahasiswa

\begin{tabular}{clcc}
\hline \multirow{2}{*}{ No } & \multirow{2}{*}{ Keterangan } & \multicolumn{2}{c}{ Siklus } \\
& & II \\
\hline 1 & Nilai Tertinggi & 75 & 100 \\
2 & Nilai Terendah & 37,5 & 50 \\
3 & Rata-Rata & 66.33 & 78.15 \\
& Persentase & 70.27 & 90.99 \\
4 & Ketuntasan & & \\
& Klasikal & & \\
Rerata Persentase & Ketuntasan & & \multicolumn{2}{|c}{80.63} \\
& Klasikal & & \\
\hline
\end{tabular}

Sehingga rata-rata untuk ke dua siklus sebesar $80,63 \%$. Hal ini telah memenuhi kriteria ketuntasan klasikal yang telah ditentukan sebelumnya yaitu minimal kekuntasan klasikal yang diperoleh sebesar $75 \%$. Selanjutnya untuk mengetahui tingkat kemampuan literasi matematika mahasiswa ditampilkan dalam Tabel 6 berikut ini. 
Tabel 6. Klasifikasi Rata-rata Persentase Penguasaan Kemampuan Literasi Matematika Mahasiswa pada Uji Coba Lapangan

\begin{tabular}{|c|c|c|c|c|c|c|c|c|c|}
\hline \multirow[b]{2}{*}{ No } & \multirow{2}{*}{\multicolumn{2}{|c|}{ Tingkat Penguasaan }} & \multicolumn{6}{|c|}{ Rata-rata Persentase (\%) } & \multirow{3}{*}{$\begin{array}{c}\begin{array}{c}\text { Total Rata-rata } \\
\text { Persentase } \\
\text { Keseluruhan }(\%)\end{array} \\
0.44\end{array}$} \\
\hline & & & \multicolumn{3}{|c|}{ Siklus I level- } & \multicolumn{3}{|c|}{ Siklus II level } & \\
\hline 1 & $100-117$ & $\mathrm{n}$ & 270 & 0 & 0 & 0 & 0 & 0 & \\
\hline 2 & $118-150$ & $\mathrm{D}^{+}$ & 0 & 0 & 0 & 0 & 0 & 0 & 0 \\
\hline & & & & & & & & & \\
\hline 3 & $1,51-1,84$ & $\mathrm{C}^{-}$ & 0 & 0 & 0 & 0 & 0 & 0 & 0 \\
\hline 4 & $1,85-2,17$ & $\mathrm{C}$ & 21,62 & 27,03 & 13,52 & 0 & 0 & 2,70 & 10.8 \\
\hline 5 & $2,18-2,50$ & $\mathrm{C}^{+}$ & 54,05 & 0 & 21,62 & 18,92 & 8.11 & 0 & 17.61 \\
\hline 6 & $2,51-2,84$ & $\mathbf{B}^{-}$ & 0 & 0 & 0 & 0 & 0 & 0 & 0 \\
\hline 7 & $2,85-3,17$ & B & 21,63 & 72,97 & 64,86 & 72,97 & 62,16 & 62,16 & 59.01 \\
\hline 8 & $3,18-3,50$ & $\mathrm{~B}^{+}$ & 0 & 0 & 0 & 8,11 & 29,73 & 0 & 6.3 \\
\hline 9 & $3,51-3,84$ & $\mathrm{~A}^{-}$ & 0 & 0 & 0 & 0 & 0 & 0 & 0 \\
\hline 10 & $3,85-4,00$ & A & 0 & 0 & 0 & 0 & 0 & 35,14 & 5.84 \\
\hline & Total & & 100 & 100 & 100 & 100 & 100 & 100 & 100 \\
\hline
\end{tabular}

Dari tabel 6 di atas dapat kita lihat untuk total rata-rata persentase keseluruhan tes pada tingkat penguasaan mahasiswa dengan tingkat penguasaan D sebesar $0,44 \%, \mathrm{D}^{+}$sebesar $0 \%$, $\mathrm{C}^{-}$sebesar $0 \%$, pada tingkat penguasaan mahasiswa dengan tingkat penguasaan $\mathrm{C}$ sebesar $10,8 \%$, pada tingkat penguasaan mahasiswa dengan tingkat penguasaan $\mathrm{C}^{+}$ sebesar 17,61\%, pada tingkat penguasaan mahasiswa dengan tingkat penguasaan $\mathrm{B}^{-}$ sebesar $0 \%$, pada tingkat penguasaan mahasiswa dengan tingkat penguasaan $\mathrm{B}$ sebesar 59,01\%, pada tingkat penguasaan mahasiswa dengan tingkat penguasaan $\mathrm{B}^{+}$ sebesar $6,3 \%$, pada tingkat penguasaan mahasiswa dengan tingkat penguasaan $\mathrm{A}^{-}$ sebesar $0 \%$, dan pada tingkat penguasaan mahasiswa dengan tingkat penguasaan A sebesar $5,84 \%$.Untuk melihat total rata-rata persentase penguasaan mahasiswa keseluran dapat dilihat dalam diagram berikut

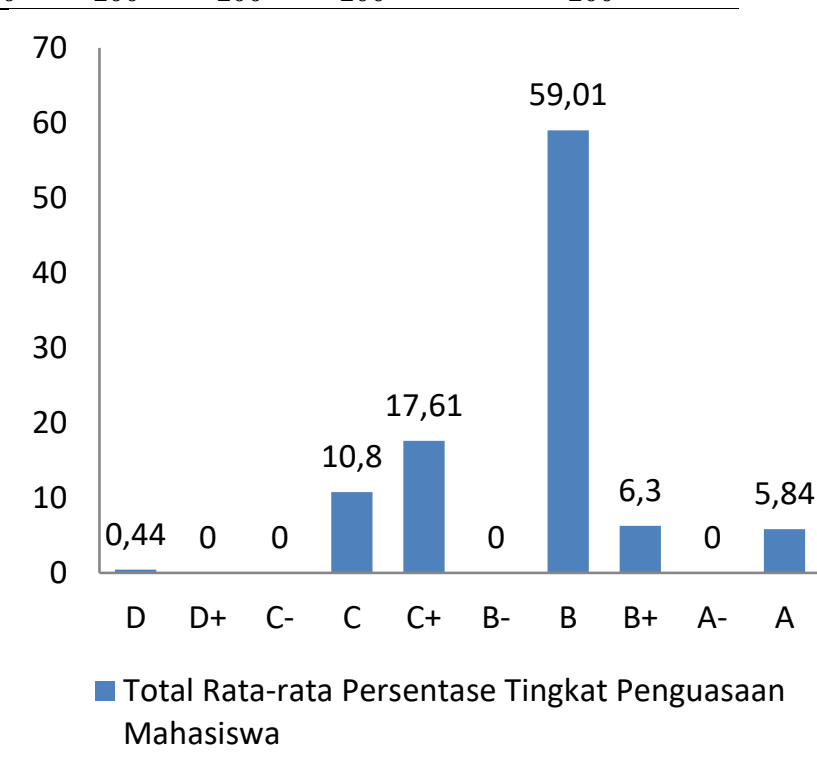

Gambar 2. Diagram Total Rata-rata Tingkat Penguasaan Mahasiswa

Diagram di atas dapat kita lihat bahwa persentase terbanyak tingkat penguasaan mahasiswa berada pada nilai B sebesar $59,01 \%$, tingkat penguasaan mahasiswa berikutnya berada pada nilai $\mathrm{C}^{+}$sebesar $17,61 \%$, C sebesar $10,8 \%, \mathrm{~B}^{+} 6,3 \%$, dan $\mathrm{D}$ sebesar $0,44 \%$, sedangkan tingkat penguasaan mahasiswa pada nilai $\mathrm{D}^{+}, \mathrm{C}^{-}, \mathrm{B}^{-}$, dan $\mathrm{A}^{-}$ sebesar $0 \%$.

Berdasarkan kriteria yang telah ditetapkan sebelumnya yaitu bahwa ketuntasan 
mahasiswa secara individual, minimal mahasiswa memperoleh nilai $\geq 2,66$ dengan predikat B- dengan syarat ketuntasan secara klasikal minimal mencapai $70 \%$. Jika dilihat secara keseluruhan maka rerata persentase ketuntasan klasikal yang dicapai oleh mahasiswa pada uji coba lapangan adalah 80,63\% hal ini sudah memenuhi kriteria ketuntasan klasikal yang telah ditetapkan dan pada tingkat kemampuan literasi matematika mahasiswa yang nilainya berada pada predikat B- sampai A sebesar 71,15\% dengan kriteria sedang. Hasil penelitian ini sejalan dengan penelitian yang dilakukan oleh Prabawati,dkk (2019) bahwa" Problem Based Learning dapat meningkatkan kemampuan literasi matematika", hal ini juga didukung oleh penelitian Kenedi dan Yullis (2017) bahwa "Komponen utama dalam literasi matematis yaitu memudahkan pemecahan masalah seharihari yang sekaligus dapat mengembangkan kemampuan matematikanya. Pembelajaran berbasis masalah merupakan salah satu model pembelajaran yang menyajikan masalah kontekstual yang dapat merangsang kreativitas pesertadidik untuk menemukan konsep dan memecahkan masalah dalam kehidupan seharihari. Oleh sebab itu adanya kaitan yang erat literasi matematis dalam pembelajaran berbasis masalah. Hasil penelitian Istiandaru, dkk; Dewi, dkk; serta Rahmat, dkk, menyatakan bahwa Problem Based Learning dapat meningkatkan kemampuan literasi matematika peserta didik

Selanjutnya berdasarkan rekapitulasi data hasil angket respon mahasiswa, diperoleh hasil respon mahasiswa di atas diperoleh rata- rata persentase untuk aspek pertama 91,22\%, aspek kedua 93,86\%, aspek ketiga $83,78 \%$,aspek keempat $94,59 \%$, dan aspek kelima 91,89\%, maka secara keseluruhan respon mahasiswa berada pada kategori sangat positif.

\section{SIMPULAN}

Berdasarkan analisis data yang dilakukan dalam penelitian, maka secara umum dapat ditarik kesimpulan bahwa model pembelajaran Problem Based Leraning melalui daring dapat digunakan untuk meningkatkan hasil kemampuan literasi matematika mahasiswa. Berdasarkan submasalah yang ada, maka dapat ditarik kesimpulan sebagai berikut. Penerapan model pembelajaran Problem Based Learning melalui during cukup baik, dari hasil observasi kemampuan dosen mengelola pembelajaran untuk keseluruhan siklus yaitu 3.60 dengan kriteria cukup baik. Pencapaian waktu ideal aktivitas mahasiswa pada pertemuan I dan II siklus I dan pertemuan I dan II siklus II telah memenuhi keenam kategori aktivitas mahasiswa dengan toleransi $5 \%$ dan batas toleransi 3 dan 5 terpenuhi. Kemampuan literasi matematika mahasiswa setelah menggunakan model Problem Based Learning melalui during sebesar 71,15\% dengan kategori sedang, dan untuk ketuntasan klasikal dari siklus I dan II sebesar 80,63\% dengan kategori telah memenuhi syarat ketuntasan klasikal. Peningkatan kemampuan literasi matematika mahasiwa menggunakan model Problem Based Leraning melalui daring mengalami 
peningkatan dari siklus I ke siklus II sebesar $20,72 \%$.

\section{DAFTAR RUJUKAN}

Abdullah, M., Firmansyah, M. A., 2013. Clinical Apporach and Management of Chronic Diarrhea. The Indonesian Journal of Internal Medicine. 45 (2) 157-165.

Dzulfikar, A., Asikin, M. \& Hendikawati, P. 2012. Keefektifan Problem Based Learning dan Model Eliciting Activities terhadap Kemampuan Pemecahan Masalah. Unnes Journal of Mathematics Education-UJME, Vol. 1, No. 1.

Hutagaol, A, S. 2015. Pengembangan Perangkat Pembelajaran Menggunakan Model Pembelajaran Berbasis Masalah untuk Meningkatkan Kemampuan Pemahaman Konsep dan Disposisi Matematis Siswa SMP [Tesis]. Medan: Universitas Negeri Medan.

Istiandaru. Dkk. 2015. Problem Based Learning (PBL) dengan Pendekatan Realistik-Saintifik dan Asesmen PISA untuk Meningkatkan Kemampuan Literasi Matematika. Jurnal Edumatica Vol 5 No. 1, April 2015. ISSN: 20882175. Hal. 1-11.

Kenedi dan Yullius.2017. Prosiding Seminar Nasional Pendidikan Guru Sekolah Pembelajaran Literasi Lintas Disiplin Ilmu Ke-SD-an: PGSD FIP UNP.

Kusumah, Yaya S. 2011. Literasi Matematis. Makalah disampaikan dalam seminar nasional Jurusan PMIPA FKIP Universitas Lampung Pada Tanggal 26 November 2011. Prosiding ISBN 978979-8150-32-8.

Madyaratri, Y D. dkk. 2019. Kemampuan Literasi Matematika Siswa Pada Pembelajaran Problem Based Learning dengan Tinjauan Gaya Belajar. Prosiding Seminar Nasional Matematika 2, Universitas Negeri Semarang, 648-658
OECD, 2016. PISA 2015 Result in Focus. New York: Columbia University.

Ojose, B. 2011. Mathematics Literacy: Are We Able to Put the Mathematics We Learn into Everyday Use. Journal of Mathematics Education 4 (1), 89-100

Prabawati,dkk. Pengembangan Lembar Kerja Siswa Berbasis Masalah dengan Strategi Heuristic untuk Meningkatkan Kemampuan Literasi Matematika

Rahmat, Hidayat. dkk. 2018. Peran Penerapan Model Problem Based Leaning (PBL) terhadap Kemampuan Literasi Matematis dan Kemandirian Belajar. Jornal for research in Mathematics Learning p-ISSN: $2621-7430$ |e-ISSN: 2621-7422 Vol. 1, No. 3, Desember 2018, 213-218.

Sugiyono. 2013a. Metode Penelitian Kuantitatif, Kualitatif, dan R\&D. Bandung: Alfabeta

Sugiyono. 2016a. Metode Penelitian Kuantitatif, Kualitatif, dan R\&D. Bandung: Alfabeta

Sugiyono. 2016b. Metode Penelitian Kuantitatif, Kualitatif, dan R\&D. Bandung: Alfabeta

Widoyoko, Eko Putro. 2015. Teknik Penyusunan instrumen Penelitian. Yogyakarta: Pustaka Pelajar. 